\title{
STABLE IONISTOR BATTERY FOR COMMUNICATION SYSTEMS Study of technological possibilities of creating ionistor batteries to ensure the transceiver systems operation stability
}

\author{
Denis R. Ivanov, Ilya M. Lerner, Sergey V. Spiridonov, \\ Department of Nanotechnology in Electronics, \\ Kazan National Research Technical University named after A.N. Tupolev-KAI, KNRTU-KAI, Kazan, Russian Federation; \\ German-Russian Institute of Advanced Technologies (GRIAT), aviap@mail.ru
}

DOI: 10.36724/2664-066X-2020-6-4-II-17

\begin{abstract}
The article describes a stable ionistor battery for infocommunication systems creating procedure. Based on a comparative analysis, the most balanced in terms of electrical characteristics, processability and availability components were selected. Using vacuum thermal resistive spraying, electrodes with a nanostructured carbon coating were manufacturedd. For this method, a structure with a high specific surface area obtaining technology has been formulated. Using two assembly methods, a cell of a stable ionistor battery has been built. It is possible to fully evaluate the physical and operational characteristics of the obtained ionistor batteries during long-term tests.
\end{abstract}

KEYWORDS: ionistor, structured carbon coating, supercapacitor, thermal vacuum resistive spraying.

\section{INTRODUCTION}

One of the reasons for the transmitting, receiving and information converting modules parasitic signals formation is supply circuits power fluctuations. The use of unstabilized power sources, pulse converters and power elements with a large spread of output parameters leads to the appearance of noise and errors in the information channels.

At the moment, there are two solutions for this problem - the use of stabilized sources powered by an external circuit, or the use of autonomous batteries [1, 2, 3]. The latter have several advantages - they are quite cheap, allows you to operate the equipment in hard-to-reach places and provide high power stability. But there are serious disadvantages, such as a limited service life and low environmental friendliness. Currently, electrochemical batteries are the most widely used. But a short service life (3-5 years), a small number of charge/discharge cycles, toxicity of components and severs requirements for operating conditions make them disadvantageous for most practical tasks.

As one of the alternative approaches to solve the tasks, caused by posed problems, is the energy storage devices new types creation $[2,4,5]$. In this paper, we examine the possibility of creating a storage device - an ionistor battery with nanostructured electrodes. The proposed design makes it possible to ensure power stability, a long service life and the ability to work in difficult climatic conditions with used the technologies high environmental safety. 


\section{A. Design rationale}

Due to the of double electric layer (DEL) ionistor structure high performance characteristics $[2,4,6]$, this technology is used to build an ionistor battery with nanostructured electrodes.

The simplest ionistor cell with a DEL construction is presented on the Fig. 1.

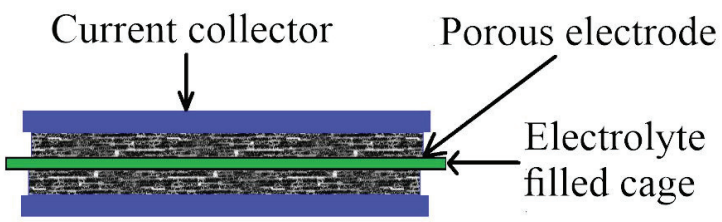

Fig. 1. Simple ionistor cell construction

A porous electrode paired with an electrolyte is involved in charge accumulation at the phase boundary. The current collector is necessary to ensure structures high chargedischarge currents. The separator electrically isolates the porous electrodes from each other while simultaneously providing high ionic conductivity for electrolyte ions.

\section{B. Electrode material selection}

Based on the chosen design, materials for the electrodes manufacturing were selected, which make an important contribution to the electric charge storage entire system efficiency [2, 6, 7]. Since the design of the electrodes can conditionally be classified as the active part (in which the charge accumulates directly) and the passive (current collector), then each of them has different requirements, and therefore the materials and manufacturing technology selection must satisfy different criteria.

The active part of the electrode is the most important and the most attention is paid to it. Analysis of existing active electrode layers materials (given in Table 1) showed that the best performance in combination with low cost are ensured when using carbon coatings. They have high conductivity and mechanical strength, a sufficient specific surface area and the technology does not require large expenditures in production.

Active electrode layers based on rare-earth materials and conductive polymers are in some cases more effective than carbon-based ones, but much more expensive or technologically less profitable.

In this work structured carbon materials were used as the main material component for electrode manufacturing, since they combine accessibility, environmental safety with high electronic conductivity (Table 2) [2, 6]. In addition, the proposed technology made it possible to achieve a high specific surface area, which critically affects the unit capacitance of the ionistor.
Supercapacitor (ionistor) electrode materials contrastive analysis

\begin{tabular}{|c|c|c|c|}
\hline \multicolumn{2}{|c|}{ Electrode material } & $\begin{array}{l}\text { Operating } \\
\text { voltage, V }\end{array}$ & $\begin{array}{l}\text { Specific } \\
\text { capacity, }\end{array}$ \\
\hline \multirow{8}{*}{$\begin{array}{l}\text { Carbon-base } \\
\text { materials }\end{array}$} & Activated carbon & 1,5 & 40 \\
\hline & Graphitic carbon & 3,0 & 12 \\
\hline & Carbon aerogel & 3,0 & 160 \\
\hline & $\begin{array}{l}\text { Ctructural carbon } \\
\text { materials }\end{array}$ & 1,5 & 140 \\
\hline & Mesoporous carbon & 0,9 & 180 \\
\hline & Meso/macroporous carbon & 0,8 & 130 \\
\hline & $\begin{array}{l}\text { Single-walled carbon } \\
\text { nanotube }\end{array}$ & 2,3 & 50 \\
\hline & $\begin{array}{l}\text { Multiwall carbon } \\
\text { nanotube }\end{array}$ & 2,5 & 13 \\
\hline \multirow{6}{*}{$\begin{array}{l}\text { Transient } \\
\text { metal oxides }\end{array}$} & $\mathrm{RuO}_{2} \cdot \mathrm{H}_{2} \mathrm{O}$ & 1,0 & 650 \\
\hline & $\mathrm{RuO}_{2}$, on carbon & 0,8 & 1000 \\
\hline & $\mathrm{MnO}_{2}$ & 0,8 & 261 \\
\hline & $\begin{array}{l}\mathrm{MnO}_{2} \text {, on activated } \\
\text { carbon }\end{array}$ & 2,2 & 29 \\
\hline & $\mathrm{Ni}(\mathrm{OH})_{2}$ & 0,8 & 578 \\
\hline & $\begin{array}{l}\mathrm{Ni}(\mathrm{OH})_{2}, \text { on activated } \\
\text { carbon }\end{array}$ & 0,9 & 194 \\
\hline \multirow{2}{*}{$\begin{array}{l}\text { Conductive } \\
\text { polymers }\end{array}$} & Poly (3-methylthiophene) & 3,6 & 25 \\
\hline & $\begin{array}{l}\text { Poly (3-methylthiophene), } \\
\text { on } \mathrm{MnO}_{2}\end{array}$ & 1,0 & 381 \\
\hline
\end{tabular}

Table 2

Carbon materials comparison

\begin{tabular}{|c|c|c|c|c|c|}
\hline 离 & 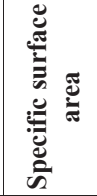 & ن⿺辶 & 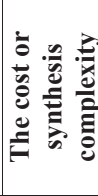 & 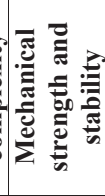 & 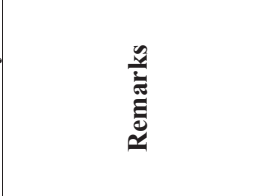 \\
\hline $\begin{array}{l}\text { Activated } \\
\text { carbon }\end{array}$ & $\begin{array}{l}\text { Very } \\
\text { high }\end{array}$ & $\begin{array}{l}\text { Very } \\
\text { low }\end{array}$ & $\begin{array}{l}\text { Very } \\
\text { low }\end{array}$ & $\begin{array}{l}\text { Very } \\
\text { low }\end{array}$ & $\begin{array}{l}\text { Requires conductive } \\
\text { additive compounds, } \\
\text { polymer binders, } \\
\text { extrusion or casing to } \\
\text { enhance some } \\
\text { characteristics, often } \\
\text { with damage to others }\end{array}$ \\
\hline $\begin{array}{l}\text { Colloidal } \\
\text { carbon }\end{array}$ & Low & $\mathrm{H}$ & & Low & $\begin{array}{l}\text { More commonly used } \\
\text { as an additive } \\
\text { component }\end{array}$ \\
\hline $\begin{array}{l}\text { Disperse } \\
\text { nanostructures } \\
\text { (carbon } \\
\text { nanotubes, } \\
\text { fullerenes, } \\
\text { etc.) }\end{array}$ & Medium & High & $\mathrm{H}$ & Low & $\begin{array}{l}\text { Requires a similar } \\
\text { approach as activated } \\
\text { carbon, because of the } \\
\text { high cost often used in } \\
\text { small quantities as an } \\
\text { additive component. }\end{array}$ \\
\hline $\begin{array}{l}\text { Carbon fabrics } \\
\text { or array of } \\
\text { carbon } \\
\text { nanotubes } \\
\end{array}$ & High & High & $\begin{array}{l}\text { Very } \\
\text { high }\end{array}$ & High & $\begin{array}{l}\text { It is extremely } \\
\text { expensive and difficult } \\
\text { to achieve high } \\
\text { reproducibility }\end{array}$ \\
\hline $\begin{array}{l}\text { Black lead } \\
\text { powder }\end{array}$ & Medium & High & Low & Low & $\begin{array}{l}\text { It has advantages and } \\
\text { disadvantages specific } \\
\text { to dispersed material, } \\
\text { but particles have a } \\
\text { high electrical } \\
\text { conductivity/ }\end{array}$ \\
\hline
\end{tabular}




\begin{tabular}{|c|c|c|c|c|c|}
\hline 苞 & 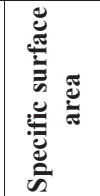 & ن & 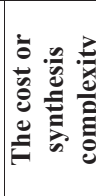 & 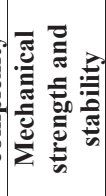 & 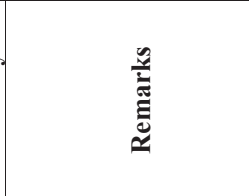 \\
\hline $\begin{array}{l}\text { Structured } \\
\text { carbon coating }\end{array}$ & Medium & High & Medium & High & $\begin{array}{l}\text { Controlled } \\
\text { morphology and } \\
\text { structure }\end{array}$ \\
\hline $\begin{array}{l}\text { Carbon aerogel } \\
\text { (black lead, } \\
\text { graphene) }\end{array}$ & $\begin{array}{l}\text { Very } \\
\text { high }\end{array}$ & High & $\begin{array}{l}\text { Very } \\
\text { high }\end{array}$ & $\begin{array}{l}\text { Very } \\
\text { high }\end{array}$ & $\begin{array}{l}\text { It was possible to } \\
\text { obtain only in recent } \\
\text { years, potentially } \\
\text { extremely productive } \\
\text { material }\end{array}$ \\
\hline
\end{tabular}

The structured carbon coating provides the best combination of characteristics, and further, the synthesis of this active electrode layer particular type is considered.

The second part of the electrode is the frame collector layer, sometimes called the current collector. The current collector material choice is given in the Table 3. The main criteria for this layer were: high electronic conductivity, mechanical stability, chemical inertness to the cell components, and availability.

Table 3

Current collector materials analysis

\begin{tabular}{|c|c|c|c|c|}
\hline & 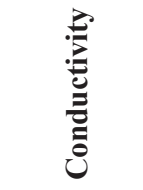 & 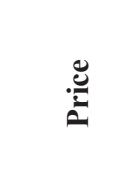 & 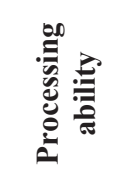 & 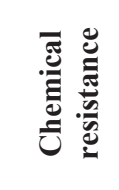 \\
\hline Aluminum & & Low & High & Medium \\
\hline Copper & y high & Medium & High & High \\
\hline $\begin{array}{l}\text { Precious } \\
\text { metals } \\
(\mathrm{Ag}, \mathrm{Au}, \mathrm{Pt})\end{array}$ & $\begin{array}{l}\text { High or } \\
\text { very high }\end{array}$ & $\begin{array}{l}\text { High or } \\
\text { very high }\end{array}$ & $\begin{array}{l}\text { High or } \\
\text { very } \\
\text { high }\end{array}$ & $\begin{array}{l}\text { Very } \\
\text { high }\end{array}$ \\
\hline Iron (steel) & Very low & Very low & Low & Low \\
\hline
\end{tabular}

All considered materials provide the necessary strength characteristics. Therefore, from Table 3 it follows that the most preferred materials for solving the task are aluminum and copper, as materials with the highest conductivity, availability and chemical resistance.

\section{Electrolyte selection}

To carry out the next step, an electrolyte for an ionistor cell capable of providing high charge-discharge currents was selected $[2,4,9]$.

Existing electrolytes for super condenser with DEL comparative analysis is shown in the table below (Table 4).

Aqueous electrolytes have high ionic conductivity, are very available, and characterized by small ion sizes, which increases the electrolyte permeability into the pores of the active part of the electrode.

Aqueous electrolytes, in their turn, are also classified into several groups (Table 5).
DEL super condensers electrolytes analysis

\begin{tabular}{|l|l|l|l|l|}
\hline & $\begin{array}{c}\text { Ion } \\
\text { conductivity, } \\
\text { S/cm }\end{array}$ & $\begin{array}{c}\text { Voltage } \\
\text { range, } \mathbf{V}\end{array}$ & Accessibility & $\begin{array}{c}\text { Ion } \\
\text { sizes }\end{array}$ \\
\hline $\begin{array}{l}\text { Aqueous } \\
\text { electrolyte }\end{array}$ & Up to 0,8 & Up to 1,23 & Very high & Small \\
\hline $\begin{array}{l}\text { Organic } \\
\text { electrolyte }\end{array}$ & Approx. 0,02 & Up to 5 & Low & Large \\
\hline Ionic liquids & Approx. 0,01 & Up to 6 & Low & Small \\
\hline
\end{tabular}

Table 5

Aqueous electrolytes classification

\begin{tabular}{|l|l|}
\hline Salines & \multicolumn{1}{|c|}{$\mathrm{KNO}_{3}, \mathrm{AlCl}_{3}$} \\
\hline Strong acids & $\mathrm{HClO}_{4}, \mathrm{HClO}_{3}, \mathrm{HNO}_{3}, \mathrm{H}_{2} \mathrm{SO}_{4}, \mathrm{HCl}, \mathrm{HI}, \mathrm{HBr}$ \\
\hline Alkalis & $\mathrm{NaOH}, \mathrm{KOH}, \mathrm{CsOH}, \mathrm{RbOH}, \mathrm{Sr}(\mathrm{OH})_{2}, \mathrm{LiOH}$, \\
& $\mathrm{Ba}(\mathrm{OH})_{2}, \mathrm{Ca}(\mathrm{OH})_{2}$ \\
\hline
\end{tabular}

Basing on the information about conductivity (Table 6), availability and environmental friendliness, there were considered to use $\mathrm{KOH}$-based electrolyte.

Table 6

Aqueous solutions peak molar mobility $\left(\mathrm{S} \bullet \mathrm{m}^{2} \bullet \mathrm{mol}^{-1}\right)$ at $25^{\circ} \mathrm{C}$

\begin{tabular}{|c|c|c|c|}
\hline Cation & $\lambda^{\infty} \cdot{ }_{i}^{10^{4}}$ & Anion & $\lambda^{\infty} \cdot 10^{4}$ \\
\hline $\mathrm{H}^{+}, \mathrm{H}_{3} \mathrm{O}^{+}$ & 349,8 & $1 / 2 \mathrm{~Pb}^{2+}$ & 70 \\
\hline $\mathrm{Li}^{+}$ & 38,7 & $1 / 2 \mathrm{Fe}^{2+}$ & 53,5 \\
\hline $\mathrm{Na}^{+}$ & 50,8 & $1 / 3 \mathrm{Fe}^{3+}$ & 68 \\
\hline $\mathrm{K}^{+}$ & 73,5 & $1 / 2 \mathrm{Ba}^{2+}$ & 63,6 \\
\hline $\mathrm{Rb}^{+}$ & 77,8 & $1 / 2 \mathrm{Ca}^{2+}$ & 59,5 \\
\hline $\mathrm{Cs}^{+}$ & 77,2 & $1 / 2 \mathrm{Sr}^{2+}$ & 59,5 \\
\hline $\mathrm{Ag}^{+}$ & 61,9 & $1 / 2 \mathrm{Ba}^{2+}$ & 63,6 \\
\hline $\mathrm{NH}_{4}^{+}$ & 73,6 & $1 / 2 \mathrm{Zn}^{2+}$ & 54 \\
\hline $1 / 2 \mathrm{Cu}^{2+}$ & 56,6 & $1 / 2 \mathrm{Cd}^{2+}$ & 54 \\
\hline $1 / 2 \mathrm{Mn}^{2+}$ & 53,5 & $1 / 3 \mathrm{Al}^{3+}$ & 63 \\
\hline $1 / 2 \mathrm{Mg}^{2+}$ & 53,0 & $1 / 3 \mathrm{Pt}^{3+}$ & 69,8 \\
\hline $\mathrm{OH}^{-}$ & 198,3 & $1 / 2 \mathrm{CrO}_{4}{ }^{2-}$ & 85 \\
\hline $\mathrm{F}^{-}$ & 55,4 & $1 / 2 \mathrm{C}_{2} \mathrm{O}_{4}{ }^{2-}$ & 74 \\
\hline $\mathrm{Cl}^{-}$ & 76,35 & $1 / 2 \mathrm{SO}_{4}{ }^{2-}$ & 80 \\
\hline $\mathrm{Br}^{-}$ & 78,1 & $1 / 2 \mathrm{HPO}_{4}{ }^{2-}$ & 57 \\
\hline I & 76,8 & $1 / 3 \mathrm{H}_{2} \mathrm{PO}_{4}^{-}$ & 12 \\
\hline $\mathrm{HS}^{-}$ & 65 & $\mathrm{HC} \quad-$ & 54,6 \\
\hline $\mathrm{NO}_{3}^{-}$ & 71,5 & $\mathrm{C}_{2} \mathrm{H}_{5} \mathrm{COO}^{-}$ & 35,8 \\
\hline $\mathrm{HCO}_{3}^{-}$ & 44,5 & $\mathrm{CH}_{3} \mathrm{COO}^{-}$ & 40,9 \\
\hline $\mathrm{ClO}_{4}^{-}$ & 67,3 & $\mathrm{C}_{6} \mathrm{H}_{5} \mathrm{COO}^{-}$ & 32,3 \\
\hline $1 / 2 \mathrm{CO}_{3}{ }^{2-}$ & 69,3 & $1 / 4\left[\mathrm{Fe}(\mathrm{CN})_{6}{ }^{4-}\right.$ & 110,5 \\
\hline $1 / 2 \mathrm{SO}_{4}{ }^{2-}$ & 79,8 & $1 / 3\left[\mathrm{Fe}(\mathrm{CN})_{6}^{3-}\right.$ & 100,9 \\
\hline
\end{tabular}

The target electrolyte concentration was determined based on the dependence shown in Figure 2. 


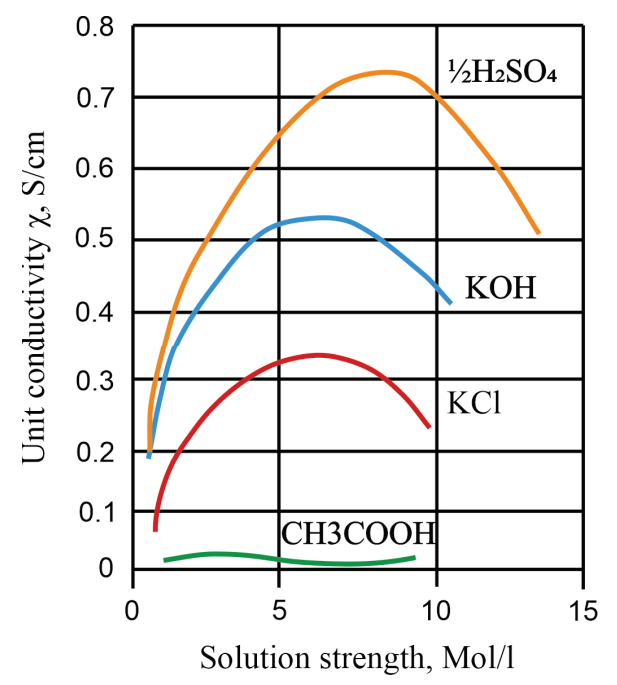

Fig. 2. Conductivity versus electrolyte concentration

Based on the graph, the highest conductivity of the $\mathrm{KOH}$ electrolyte is achieved at a concentration of $6 \mathrm{~mol} / \mathrm{L}[10]$.

\section{Separator material selection}

The last element of the design is a separator - a porous material that provides electrolyte retention and opposite electrodes electrical insulation. Among the separation materials intended for electrochemical current sources, the main ones are the polypropylene, polyethylene, fiberglass, pulp and paper and fluoroplastic materials. It was found that the electrode material specific capacitance weakly depends on the nature of the separator. A weak correlation is also traced between the thickness of the separator and its impedance. Only porosity has a marked effect on impedance. Thus, the main criteria for the separator are high porosity and small thickness [11].

Based on the available commercial separator models, it was decided to use the YN-BS001 fiberglass separator (Fig. 3 ). Its thickness is about 300 microns, and porosity is not less than $85 \%$.

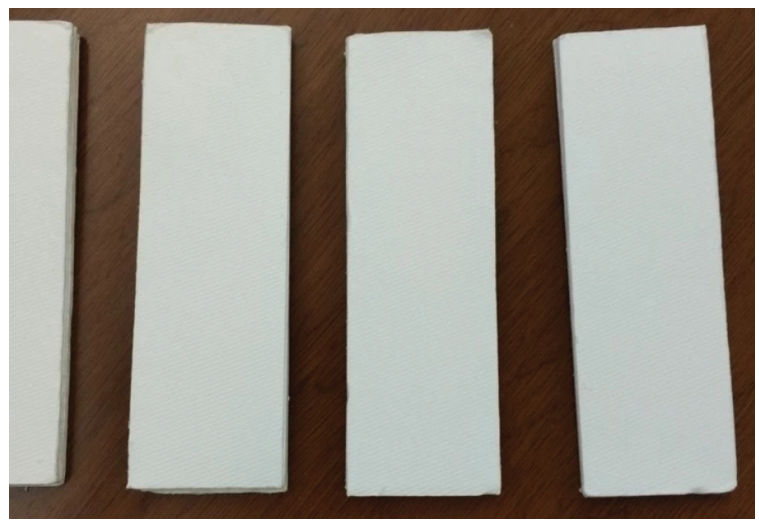

Fig. 3. YN-BS001 separator

\section{PRACTICAL ASPECTS OF CONSTRUCTION PROBLEM SOLUTION}

The main task of the technological cycle of the work was the active layer of electrodes structured carbon coating formation. The considered methods for evolved carbon coatings producing have led to the conclusion about the promising possibilities of direct thermal vacuum resistive spraying [8]. This method allows obtaining both flat films and evolved crystallite-based structures depending on the spraying mode. For this reason, in further work this approach was chosen as the main one.

As the electrodes current collector frame layers, aluminum and copper foil with a thickness of $20 \mu \mathrm{m}$ and a purity of no worse than $99.5 \%$ were used. Before applying the active layer, the surface of the foil was subjected to cleaning in a solution of ethanol $(\mathrm{C} 2 \mathrm{H} 6 \mathrm{O}, 95 \%)$ and drying in an oven for 15 minutes at a temperature of $85^{\circ} \mathrm{C}$.

Substrates prepared in this way were placed in the working chamber of the Type Jee thermal vacuum-deposition system. This system implements two methods of thermoresistive spraying - indirect heating and direct evaporation of carbon material. The second method was used in the work to form a defined carbon structure.

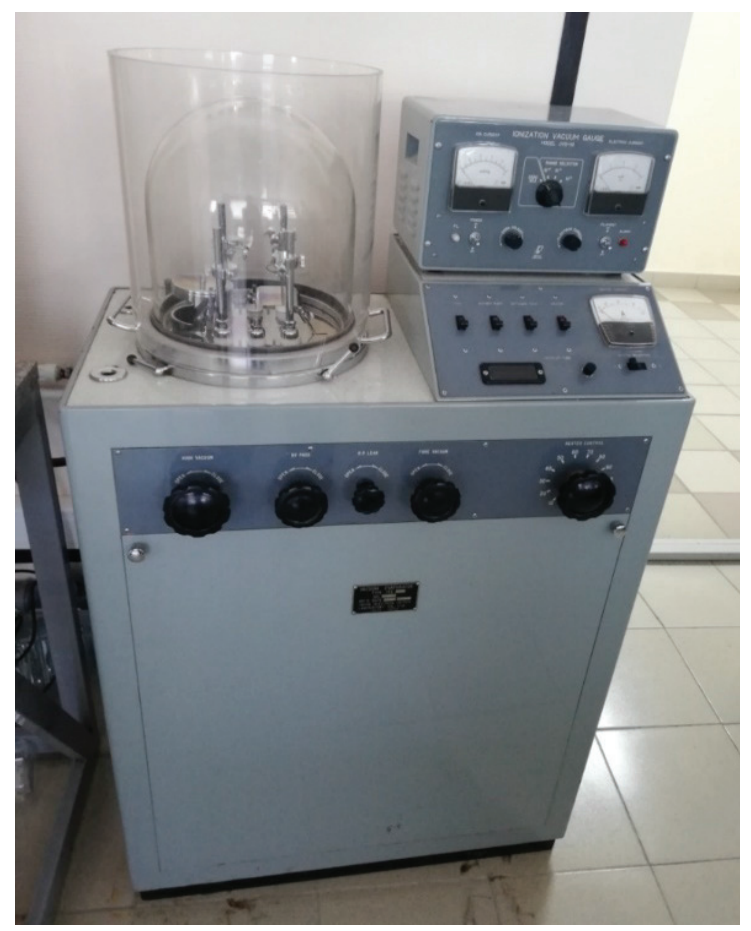

Fig. 4. Vacuum Evaporator Type Jee thermal vacuum-deposition system

As the vaporized substance, graphite rods of $99.99 \%$ purity are used. They are sharpened in order to minimize the diameter of the mutual contact. The rods were placed in the chamber at a distance of $10-15 \mathrm{~cm}$ from the substrates (Figure $5)$. 


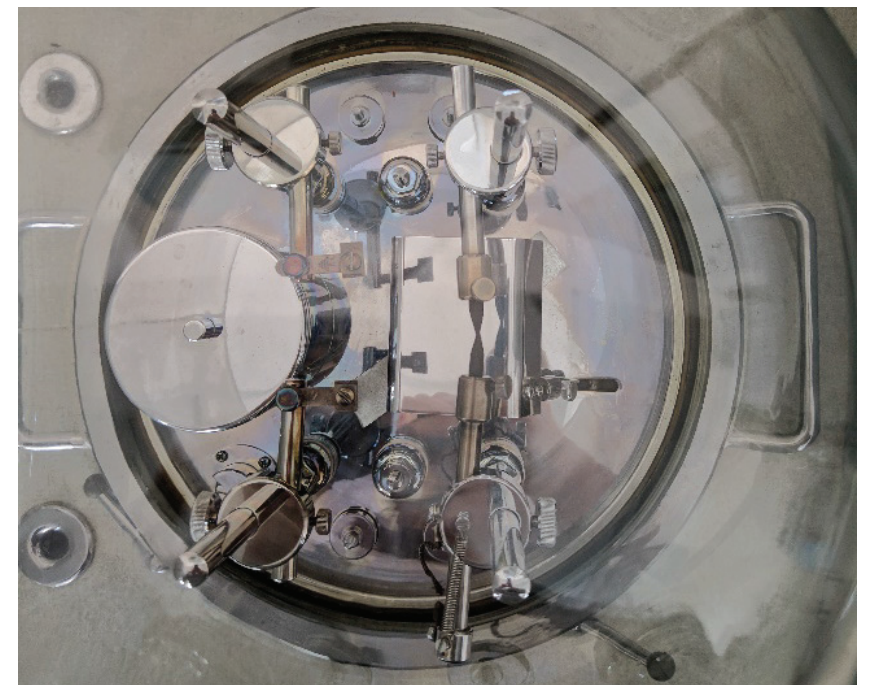

Fig. 5. Preparation before spraying

Spraying was performed at a vacuum level of about 10-5 $\mathrm{mm} \mathrm{Hg}$. Before spraying, graphite rods were annealed with a closed shutter at a current value of $15 \mathrm{~A}\left(900-950^{\circ} \mathrm{C}\right)$ for 5 minutes. Temperature control was carried out using a remote infrared pyrometer.

The main spraying process was carried out in two stages the carbon sublayer creation and the developed carbon surface formation. The sublayer was deposited for 90 minutes at a current of $15 \mathrm{~A}\left(900-950^{\circ} \mathrm{C}\right)$. This stage is necessary to ensure the required adhesion and passivation of the foil surface in order to minimize the electrolyte influence on it. The second stage of spraying was carried out at a current of 24 A for 180 minutes. The temperature of the rods reached 1500 ${ }^{\circ} \mathrm{C}$. Thus, the total spraying time was 4 hours 30 minutes.

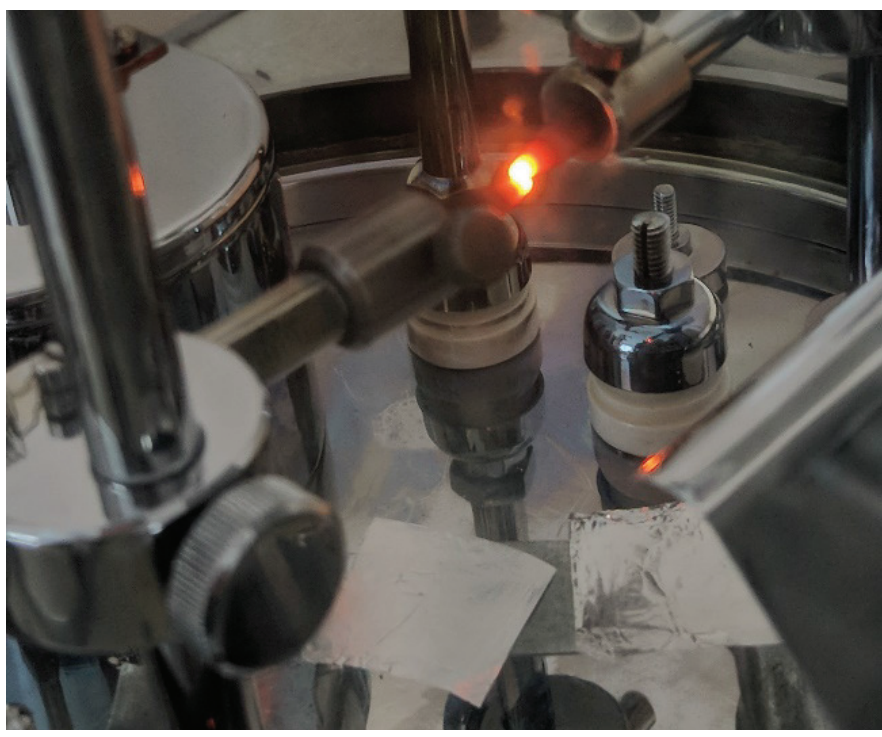

Fig. 6. Evaporation on the conducting foil process

\section{OBTAINED SPRAYING RESULTS INVESTIGATION}

To evaluate the presented technology recovery results, scanning electron microscopy with the elemental composition energy-dispersive analysis possibility were used. The study was carried out using a Carl Zeiss Auriga CrossBeam microscope.

At the first stage, the electrode main layer surface (current collectors based on aluminum and copper foil) was evaluated. Their surface before spraying can be estimated from the images in the Figure 7:

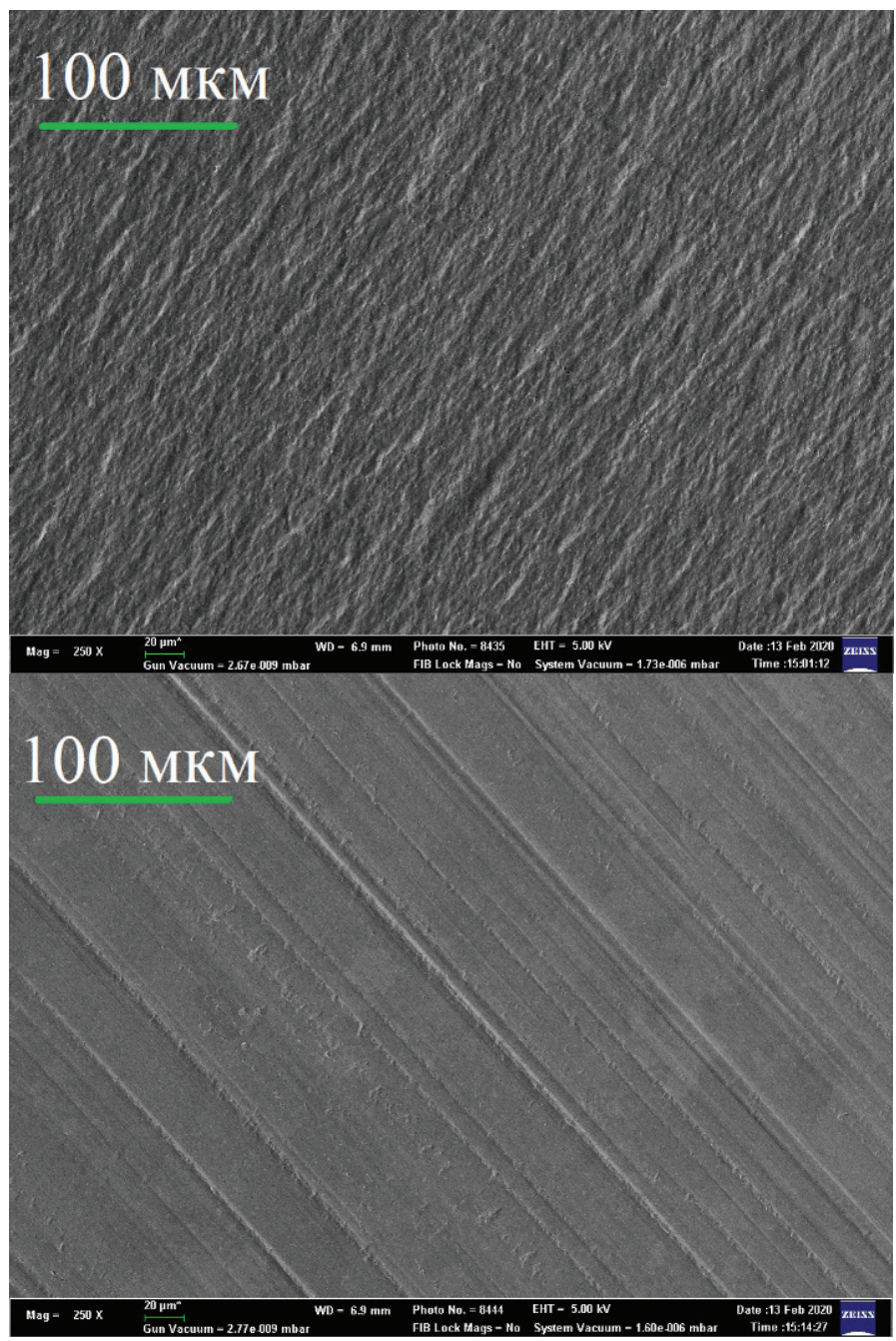

Fig. 7. Aluminium foil SEM images. Matte side exposure on the top, glossy on the bottom

Comparing the images, it can be seemed that the foil matte side has a more evolved and chaotic surface structure, which can affect the resulting coating characteristics.

Next, after carbon coating deposition, SEM images were obtained (Figure 8): 

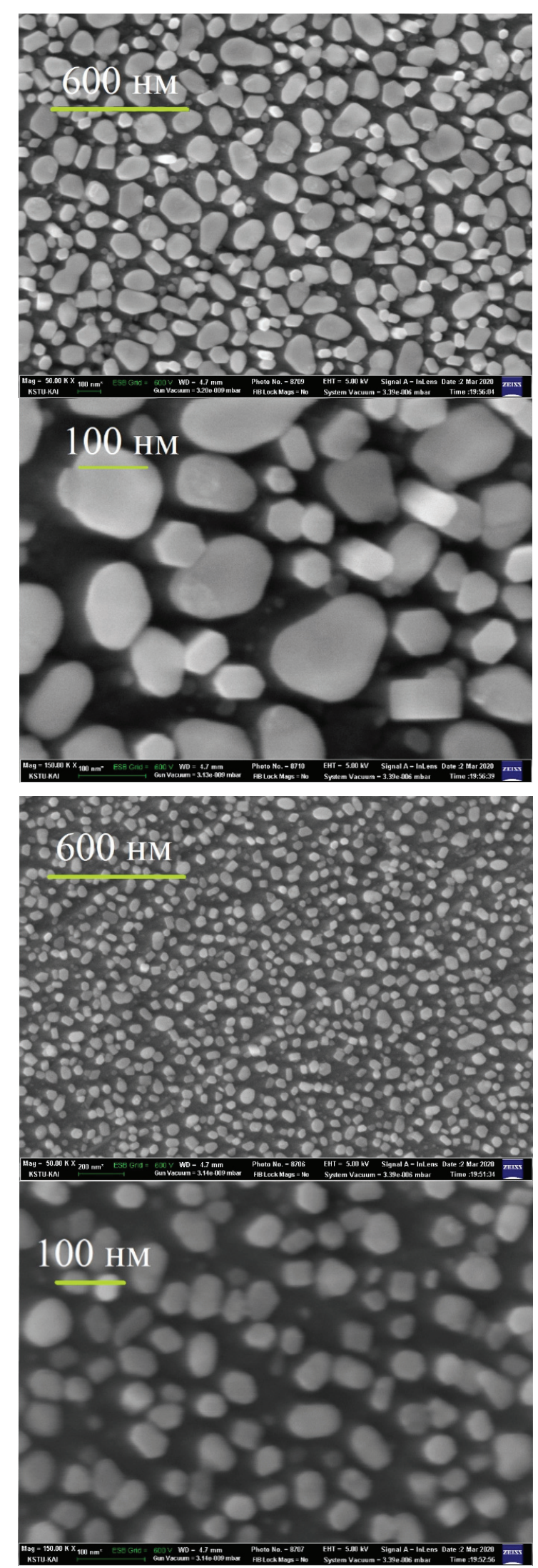

Fig. 8. SEM images of the matte (two on the top) and glossy (two on the bottom) side of an aluminum foil with a nanostructured carbon coating with magnification of 50 and 150 thousand times
The coating consists of submicron diameter crystal-like longitudinal structures. On the matte side formations are denser and larger. A more detailed inspection of the surface of the matte side is shown in the image below (Figure 9).

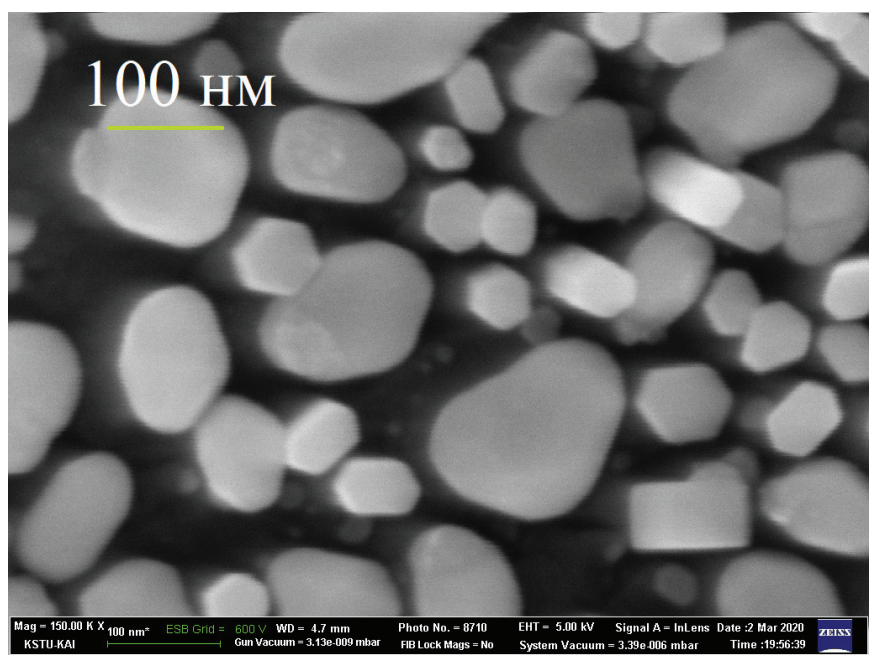

Fig. 9. Structured carbon coating increased 150 thousand times

The diameter of the structures at the baseline varies from $5 \mathrm{~nm}$ to $200 \mathrm{~nm}$. The average particle diameter is $60 \mathrm{~nm}$. The average distance between particles is $40 \mathrm{~nm}$. The shape of the particles base varies from an irregular ellipse to a regular hexagon. It can be assumed that particles having the shape of a regular hexagon are a carbon single crystal with $\mathrm{sp}-2$ bond hybridization. Due to the fact that the electron beam falls on the substrate at a slight deviation from the right angle, the dark background formation, indicating an elongated shape, can be seen.

For a more detailed study of the surface, it was carried out using an NT-MDT Nanoeducator II scanning probe microscope. The study confirmed that the structures are in the form of rods with a height of $200 \mathrm{~nm}$ to $850 \mathrm{~nm}$.

A preliminary assessment of the resulting structure allows us to conclude that the surface development indicators, hence the specific surface area, are high. The latter is a key parameter that determines the ionistor cell final capacity

\section{Electrolyte preparation}

To prepare $25 \% \mathrm{KOH}$ electrolyte, $100 \mathrm{ml}$ of distilled water and $34 \mathrm{~g}$ of chemically pure $\mathrm{KOH}$ were used. To accelerate the alkali in water dissolution reaction passage, heating and mixing were carried out using a magnetic stirrer. Next, the solution was isolated from air and settled for 3-6 hours until completely clarified.

\section{ASSEMBLY TECHNIQUE}

At the final stage, stacking and coiling ionistor manufacturing technology assembly methods are considered. $[2,4]$ In simplest case, the cell is assembled as a hermetically 
sealed package, with two manufactured electrodes embedded in it, between which there is a separator preventing electrical contact. The electrolyte is poured during the electrodes placement, or after sealing the packet with subsequent hole sealing. Electrical contacts may be formed from an ongoing electrode portion that is hermetically-sealed from the stack. Due to the fact that the electrodes are usually flat, this practically does not affect the tightness of the stack.

When using coiling manufacturing technology, at least four layers are used, two of which are "positive" and "negative" electrodes, and two others are separators. They are located alternating each other so that there is no electrical contact between the electrodes during winding. The current leads can be pre-attached to the current collector (preferably in several places, to reduce the equivalent series resistance), as shown in the design example (Figure 10).

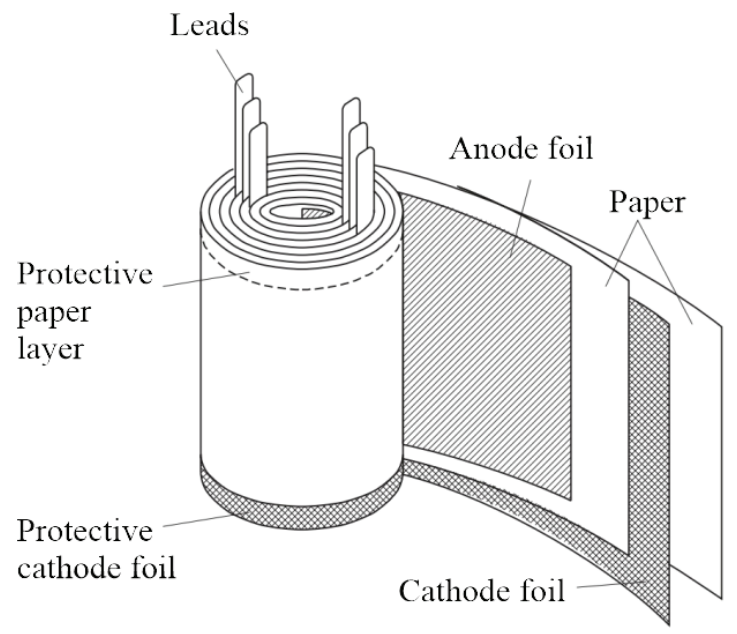

Fig. 10. Ionistor battery construction example [12]

It is also possible to provide such arrangement of electrodes and separators that winding each end surface forms an electrical output of one of the electrodes. Refueling with electrolyte is carried out before winding or when placing the finished structure in a special case. The housing must be hermetically-sealed, durable and chemically inert to the supercapacitors internal environment. Each assembly method has its advantages and disadvantages. In the case of stacking technology, the required voltage inside one battery is easily achieved due to the cells series coupling. Coiling technology is preferable for production due to the ability to scale. Both methods were used in the work.

\section{CONCLUSION}

Within the framework of this study, the stabilized autonomous power source based on an ionistor battery creating possibility was considered. The main approaches to such energy storages design were considered. A complete technological study of all stages of finished cell item obtaining is carried out. During experimental work steps, a proprietary approach to electrodes active part obtaining was proposed. All technological steps have been carried out to form the ionistor cell and its assembly elements. Performed operations allow us to conclude the possibility of such power sources cheap and maintainable production. However, a more detailed study of all operational properties is required.

\section{Acknowledgments}

The article authors are grateful to the "Prikladnye Nanotehnilogii" (Applied Nanotechnology) core facilities center of Kazan National Research Technical University named after A.N. Tupolev for providing research technical opportunities.

\section{REFERENCES}

[1] Wang S., Wei T., Qi Z. (2008) Supercapacitor energy storage technology and its application in renewable energy power generation system. Proceedings of ISES World Congress 2007, Vol. I, pp. 2805-2809.

[2] Raza, W., et al.. (2018). Recent advancements in supercapacitor technology. Nano Energy, 52, pp.441-473.

[3] Moftah A., Al Shetiti A. (2015) Review of Supercapacitor Technology. Int. J. Comput. Sci. Electron. Eng. V. 3(3). pp. 226-231.

[4] Kötz, R. and Carlen, M. (2000). Principles and applications of electrochemical capacitors. Electrochimica Acta, 45(15-16), pp.2483-2498.

[5] Gautham Prasad, G., Shetty, N., Thakur, S., Rakshitha and Bommegowda, K.B. (2019). Supercapacitor technology and its applications: a review. IOP Conference Series: Materials Science and Engineering, 561, p. 012105.

[6] Lewandowski, A. and Galinski, M. (2007). Practical and theoretical limits for electrochemical double-layer capacitors. Journal of Power Sources, 173(2), pp. 822-828.

[7] Tabarov, F.S. (2019). Obtaining and properties of fibrous carbon materials for supercapacitor electrodes. Ph.D. thesis in Engineering Science. $115 \mathrm{p}$.

[8] Vangari, M., Pryor, T. and Jiang, L. (2013). Supercapacitors: Review of Materials and Fabrication Methods. Journal of Energy Engineering, 139(2), pp. 72-79.

[9] Jónsson, E. (2019). Ionic liquids as electrolytes for energy storage applications - A modelling perspective. Energy Storage Materials, 25. pp. 827-835.

[10] Svarovskaya, N.A., Kolesnikov, I.M. and Vinokurov, V.A (2017). Electrochemistry of electrolyte solutions ["Elektrohimiya rastvorov elektrolitov"]. Moscow: Publishing Center of the Russian State University of Oil and Gas (NRU) named after I.M. Gubkin, $66 \mathrm{p}$.

[11] Chaika, M.Y. (2012). The main types of separation materials in supercapacitors with non-aqueous electrolyte ["Osnovnye tipy separacionnyh materialov v superkondensatorah s nevodnym elektrolitom”]. Vestnik VGTU, 6, pp. 57-60.

[12] Popel, O.S., Tarasenko, A.B. and Kolomiets, Y.G. (2012). Electric energy storage devices for use in renewable energy power plants.[" Nakopiteli elektricheskoj energii dlya ih ispol'zovaniya v energoustanovkah na vozobnovlyaemyh istochnikah energii”] Moscow: M.V. Lomonosov Moscow State University, p. 49. 